\title{
Quasi-Periodicity of the Black Sea Wind Spatial-Temporal Variability and Its Relation with the North Atlantic Oscillation phases
}

\author{
Yu. N. Goryachkin, A. N. Zhukov*, N. E. Lebedev, A. A. Sizov \\ Marine Hydrophysical Institute, Russian Academy of Sciences, Sevastopol, Russian Federation \\ *e-mail: anzucov@mail.ru
}

\begin{abstract}
Quasi-periodic features of the inter-annual and inter-decadal spatial-temporal variability of the wind speed absolute value $(W)$ in the Black Sea area are assessed based on a series of 60-100-year-long direct observations performed at eight coastal stations, and also on the reanalysis data obtained from the NDP-048, WDC, NCDC, NCEP/NCAR (1948-2011) and MERRA (1980-2015) arrays. Three groups of oscillations with the periods $T$ about $60-90,20-40$ and 3-15 years that present in the $W$ direct data are shown by means of the wavelet analysis. As for long-period oscillations $(T \sim 60-90$ years), possible relations of such quasi-periodicity with the phases of the North Atlantic Oscillation index characterizing the atmospheric circulation features are investigated. Calculated according to the MERRA array reanalysis, the mean anomalies of January - February average $W$ series separately for groups of years with the values of the NAO index $>+1$ and $<-1$ demonstrated in their dynamics the values of different signs for the same Black Sea areas. It is revealed that during the periods when the index positive phase is mainly predominant, the $W$ positive anomaly is formed over the southwestern, south-eastern and eastern parts of the sea adjacent to the coast at a distance 20-100 km from it, and the $W$ negative anomaly - over the rest of the sea. During the years when the index phase is mainly negative, the signs of the $W$ anomalies over almost the same regions change to the opposite ones.
\end{abstract}

Keywords: the Black Sea, wind speed module, inter-annual variability, quasi-periodicity, North Atlantic Oscillation.

DOI: 10.22449/1573-160X-2017-5-42-50

(C) 2017, Yu. N. Goryachkin, A. N. Zhukov, N. E. Lebedev, A. A. Sizov

(C) 2017, Physical Oceanography

\section{Introduction}

Climate variability study and prediction are among the most important tasks of Earth sciences being of high applied significance [1, 2]. To diagnose and predict the Black Sea condition, the parameters of the wind regime are used, since the tangential wind stress directly affects the sea waves, circulation and mixing of water and indirectly - the thermal and water balance.

Main results of wind research in the Black Sea area are presented in $[3,4]$. They showed the presence of significant negative linear trends in the series of mean annual wind speeds and the frequency of storms in the $20^{\text {th }}$ century. In [4] it was noted that since the beginning of the 2000s, there was a tendency to increase the frequency of storm winds practically at all hydrometeorological stations. However, the study of the cyclicity of these processes was almost neglected.

Search and study of the wind regularities in the inter-annual variability and their relations with the quasi-periodicity of macro-circulation processes in the atmosphere have been still insufficiently developed [5, 6]. Therefore, the research of long-term trends in variation of the wind conditions is one of the most important practical tasks in studying the wind field variability in the Black Sea area. 
From this perspective this paper is aimed to study the quasi-periodic properties of the interannual and inter-annual variability of the wind speed module in the coastal area of the Black Sea, as well as the inter-annual variability of its spatial structure.

\section{Initial data and methods}

Object of the present research is the temporary variability of the amplitudes of the individual components of the oscillations of the wind velocity module mean annual values (W, $\mathrm{m} / \mathrm{s}$ ) in the atmosphere surface layer in the Black Sea area, bounded by $20-55{ }^{\circ} \mathrm{E}$ and $30-55{ }^{\circ} \mathrm{N}$ coordinates. The analysis method applied is described in [7].

In the study arrays of atmospheric parameter station measurements NDP-048 (URL: http://cdiac.ornl.gov/ftp/ndp048/), Russian part of the World Data Center (WDC) (URL: http://meteo.ru/mcd/metdata.html) and National Center for Climate Data, USA (NCDC) (URL: http://gis.ncdc.noaa.gov/map/viewer/\#app=cdo\&cfg=cdo\&theme=temp\&layers=1).

To check and correct these arrays, separate series of mean monthly $W$ values from archives of Marine Hydrophysical Institute RAS and Sevastopol branch of the Zubov State Oceanographic Institute were applied.

The analysis of the $W$ station data is based on their wavelet transform (WT) using the complex Morlet wavelet of the form $\psi(t)=\exp \left(-t^{2} / 2+i 2 \pi t\right)$, close to the harmonic oscillations, and a normalization allowing the direct estimation of the harmonics' amplitudes [8]. Before the WT applying, linear trends and constant components were removed from the $W$ series.

Such series are indicated in the text as $W_{0}$. In order to visualize the phases of the quasi-harmonic oscillations revealed in the $W_{0}$ series, the WTs presented in all the figures below were carried out in terms of the Morlet wavelet real part: $\operatorname{Re}(\psi(t))=\exp \left(-t^{2} / 2\right) \cos (2 \pi t)$. The periods of these oscillations were defined as the points of the scale axis corresponding to the maxima of their $S$ amplitude wavelet spectra (representing the average of modules of the WT coefficients with a given period for all time instants). The instantaneous amplitudes of oscillations are along the WT sections through these points along the time axis. Based on the results of the complex WT, the skeletons were constructed. These are the WT local peaks, the tracks of which clearly represent the temporal evolution of the periods of the revealed quasi-harmonic components of the $W_{0}$ series.

Additional data sources for the Black Sea wind were the reanalysis arrays, such as NCEP/NCAR for 1948-2011 on 2.5 ${ }^{\circ}$ grid (URL: http://www.esrl.noaa.gov/psd/data/reanalysis/reanalysis.shtml) [9] and MERRA for 1980-2015 on $0.33^{\circ}$ grid longitudinally and $0.5^{\circ}$ latitudinally (URL: http://disc.sci.gsfc.nasa.gov/MDISC/dataprods/merra_products.shtml) [10].

\section{Analysis of the results obtained}

Fig. 1 shows the results of WT of the longest ( 100 years) $W_{0}$ series according to the data of four Crimean coastal stations (Evpatorya, Sevastopol, Yalta and Feodosiya) from 1915 to 2014, including their skeletons and amplitude wavelet spectra. They made it possible to identify the main quasi-harmonic oscillations with periods $T \sim 60-90,20-40$ and 3-15 years. 

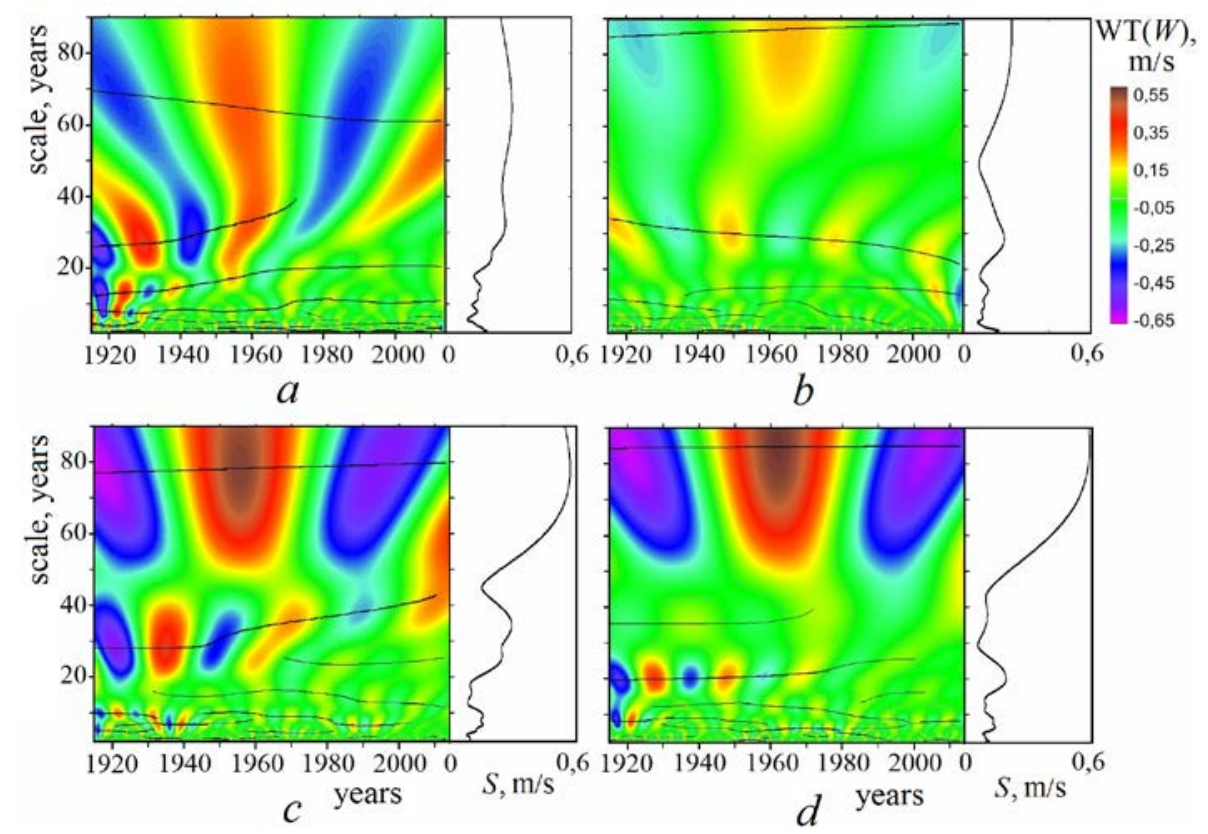

Fig. 1. Patterns of the WT coefficients of $W_{0}$ series with the superimposed skeletons (left) according to the data of the stations in Evpatorya (a), Sevastopol (b), Yalta (c) and Feodosiya (d) from 1915 to 2014 in a single scale and their global amplitude spectra $S$ (right)

Thus, the $W_{0}$ series variability has a quasi-periodic character with a predominance of long-period ( $T \geq 60$ years) and medium-period ( $15<T<40$ years) oscillations. At the same time, for different observation stations on the Crimean coast, the low-frequency components of $W_{0}$ series wavelet spectra also differ: according to the Evpatorya station data in the $W_{0}$ spectrum the oscillation from $T \sim 65$ years dominates, Sevastopol $-\sim 82$ years, Yalta $-\sim 75$ years and Feodosiya $-\sim 85$ years (Fig. 2, $a$ ).

The $W_{0}$ series components also possess their own features in smaller periods. Thus,-they are more pronounced in the band of short-period oscillations ( $T<10-15$ years), while at all the stations the medium-period oscillations have the most unstable amplitudes (Fig. 2, b, c). This figure also shows the presence of phase shifts in the oscillations of the average period between observation stations against the general background decrease in their amplitudes by $1.5-5$ times. An exception is the oscillation with $T \sim 28-35$ years (the Feodosiya station) - its amplitude, on the contrary, has increased slightly for all the time of observations.

As can be seen in Fig. 1, 2, the Evpatorya and Feodosiya stations are mostly different by their spectra structure and the dynamics of their individual components, the closest are the Sevastopol and Yalta stations. At the same time, there is a partial similarity between the Yalta and Feodosiya stations. Consequently, these features of the spatial structure of the wind field on the Crimean coast make it possible to divide it into the eastern and western parts approximately along the Yalta region. 

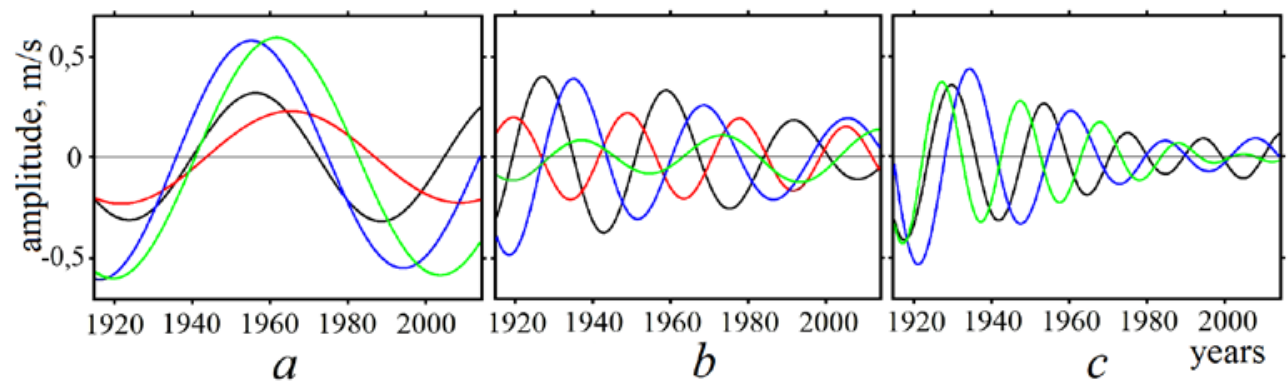

Fig. 2. $W_{0}$ series variability components according to the WT decomposition results with the periods of 60-100 (a), 28-35 (b) and 20-25 years $(c)$ of the stations in Evpatorya (black curves), Sevastopol (red curves), Yalta (blue curves) and Feodosiya (green curves)

Close results were obtained for shorter (with duration of 57-85 years) $W_{0}$ series of stations located on the northern, western, eastern and southern shores of the sea. Here the data on Odessa (1932-2016), Constanta (1952-2016), Sinop (1935-2013) and Batumi (1959-2016) (Fig. 3) are presented. In the spectra of these $W_{0}$ series, dominating are oscillations with $T \sim 38-50,59-70,56-62$, and 57 years respectively.
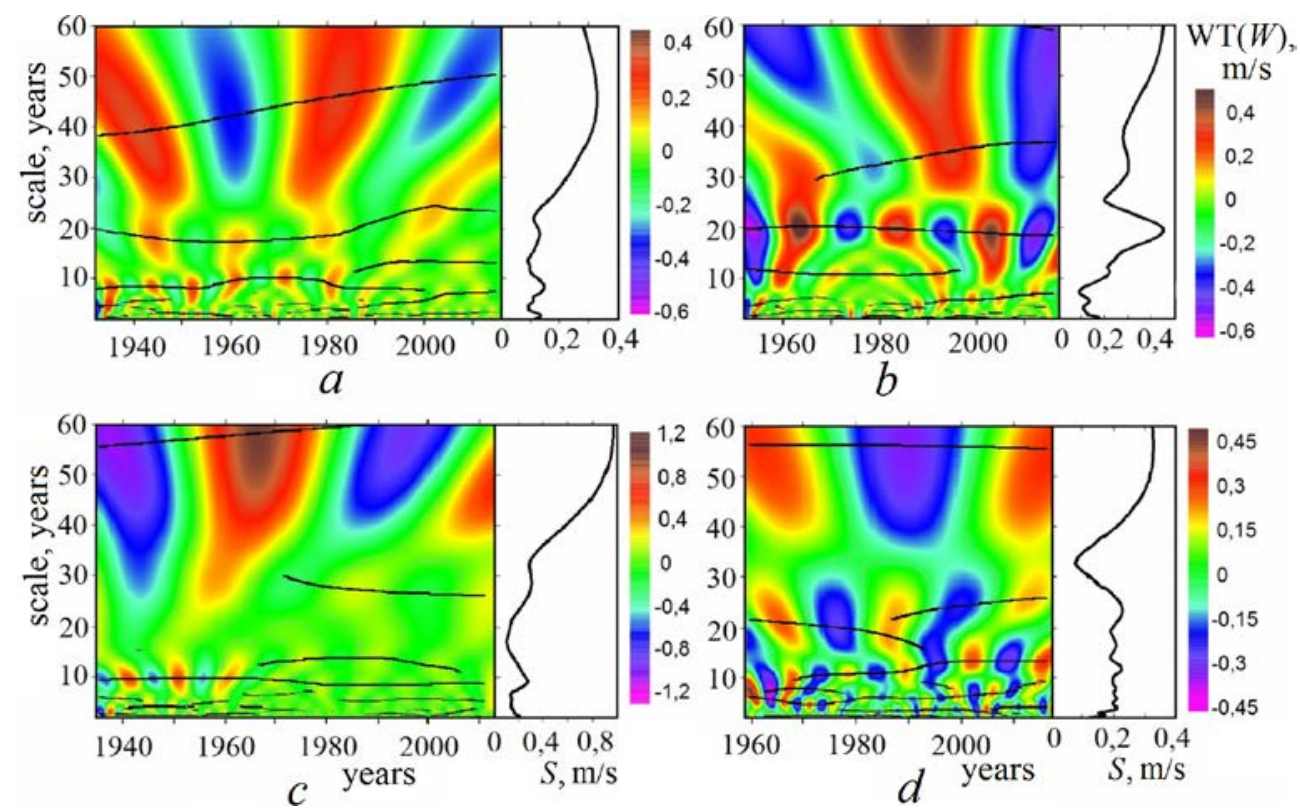

Fig. 3. Patterns of the WT coefficients of $W_{0}$ series with the superimposed skeletons (left) and their global amplitude spectra $S$ (right) of the stations in Odessa ( $a$ ), Constanta (b), Sinop (c) and Batumi (d)

At that, the width of the long-period oscillation spectral line, according to the Odessa station data, is specific to the superposition of two oscillations with periods of 30-40 and 60-80 years. But more accurate estimates of this oscillation parameters are possible for a series of several decades longer. It should be noted 
here that the results of spectral analysis (Fourier extended with Shuster periodograms, wavelet) of the quasi-periodic series on a segment slightly exceeding the period of the lowest frequency oscillation essentially depend on the presence of higher frequency oscillation close to it and the ratio of their periods, amplitudes and initial phases. This circumstance, significantly limiting the accuracy of determining the low-frequency component periods, is overcome only by an increase of the studied series length.

Spectral analysis of the $W_{0}$ series of up to 50 year duration, according to data from about twenty Black Sea stations, also showed the presence of quasi-harmonic oscillations with periods $T \sim 20-40$ and 3-15 years.

Many publications of recent decades are devoted to studying of the interrelationships between planetary and regional processes. The North Atlantic Oscillation Index (NAO) refers to the number of indicators associated with the concept of global atmospheric oscillations [11, 12]. According to the numerous studies, the NAO largely affects the weather in a majority of European countries during winter season. This is due to the fact that the atmospheric pressure gradient between the Azores and Icelandic centers of the atmosphere effect determines the western disturbance intensity in the middle latitudes [13].

As the atmospheric circulation intensifies in winter season, the NAO index values calculated for December - March are more often used. In this paper, Hurrell DJFM North Atlantic Oscillation Index (Station-Based) series for 1864-2014 was taken as the NAO index winter values. [14]. Periodicity of different scales and the non-stationary nature of the process are clearly manifested in the pattern of the WT components of the NAO index (Fig. 4). Here the oscillations with $\mathrm{T} \sim 60-80,40$, 15-25, 2-12 years are clearly seen. Thus, the oscillations with periods close to the periods of the $W$ series components are specific for the NAO index series. This is because the atmospheric circulation in the Atlantic-European sector, characterized by the NAO index, determines the wind field variability in the Black Sea area. To demonstrate this, the reanalysis data is used.

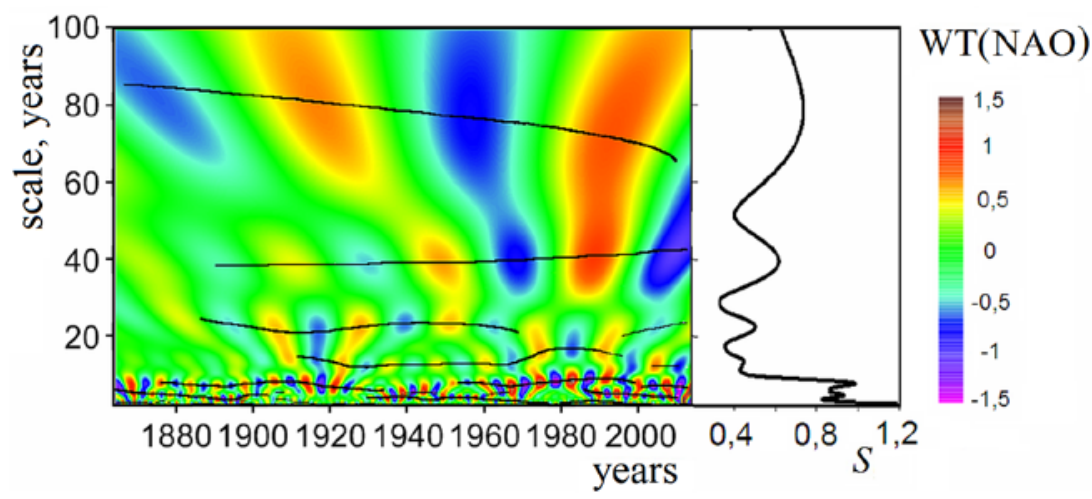

Fig. 4. Wavelet transform of the NAO index series from 1864 to 2014 with the superimposed skeleton (left) and its global amplitude spectrum (right)

The NCEP/NCAR wind field structure being temporally averaged over total reanalysis time interval can be divided into four regions of increased and decreased $W$ values with their centers located crosswise in the Black Sea area [15]. The mean annual $W$ values taken from the NCEP/NCAR data permitted to represent the $W$ 
spatial structure in the Black Sea area in the decades corresponding to the negative (1955-1965) and positive (1990-2000) phases of the 60-to-80 year long NAO index oscillation [16]. The $W$ spatial structure for winds with periods $>60$ years, calculated from these samples, is shown in Fig. 5, $a, b$. As can be seen, in the decade when the negative values of the NAO index predominate, the wind speed in the Black Sea area is higher than in decade with the predominance of positive NAO values. Thus, the changes in the $W$ field structure associated with the atmospheric circulation come down to variations in the position of the centers and the sizes of increased and decreased $W$ value regions. In 1955-1965 (the negative phase of the 60-to-80 year long NAO index oscillation), regions of increased $W$ values shifted over the Black Sea towards each other, merging together over practically the entire water area. In 1990-2000 (the 60-to-80 year long NAO index oscillation), on the contrary, over the greater part of the sea in its center and in the east, under merging were regions of decreased $W$ values.
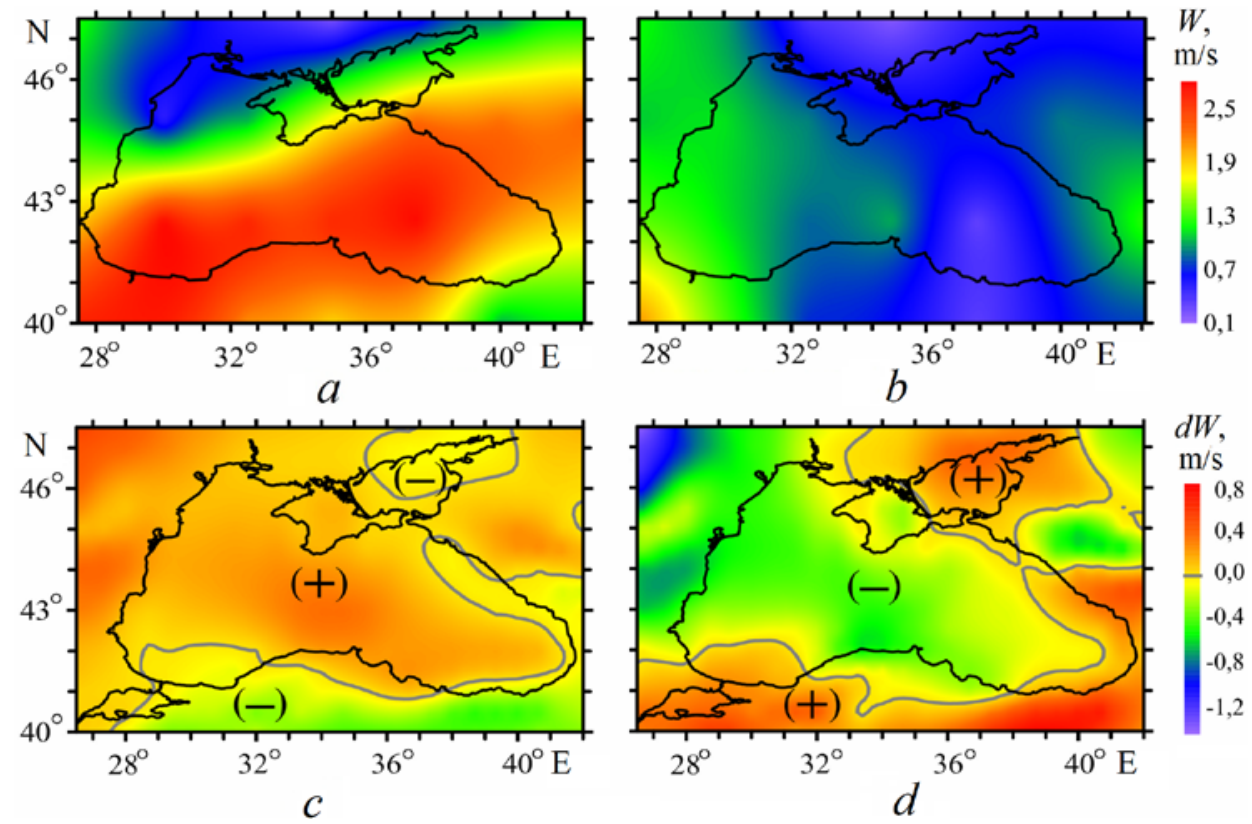

Fig. 5. Temporally averaged Black Sea $W$ fields for winds with periods $>60$ years, for the decades corresponding to the negative (1955-1965) (a) and positive (1990-2000) (b) phases of the 60-to-80 year long NAO index oscillation according to the NCEP/NCAR reanalysis data. $W$ anomaly fields of the Black Sea according to the MERRA reanalysis data for 1980-2015 averaged for a set of years, when the $N A O$ index $<-1(c)$ and $>+1(d)$

According to the MERRA reanalysis data on a smaller grid, the mean anomalies of January - February averaged $W$ series were calculated separately for groups of years with the values of the NAO index $>+1$ and $<-1$. In their dynamics these fields demonstrated the anomalies of different signs for the same Black Sea areas (Fig. 5, $c, d$ ). Fig. 5 shows that the action of all groups of quasi-harmonic $W$ oscillations in combination with the mesoscale spatial inhomogeneity of the wind 
field can lead to multidirectional trends in the $W$ variability for the different Black Sea observation stations in various time intervals.

\section{Discussion}

Explanation of the obtained results could be as follows. After the 1960s, there was a surface pressure increase resulted in an increase in the number of events of anticyclonic atmospheric circulation over the Black Sea area [17, 18]. Such a tendency led to a negative $W$ trend. At the stations of Evpatorya, Sevastopol, Yalta, Feodosya, Odessa, Constanta, Sinop and Batumi, it was about $(-7.17,-14.5,-2.8,-24.7,-29.1,-35.6,-15.9,-3.7) \cdot 10^{-3} \mathrm{~m} / \mathrm{s} / \mathrm{year}$. This process was not monotonous, which was, apparently, due to the interannual variability of atmospheric circulation, manifested in a position change of cyclone trajectories in the Atlantic-European sector [19]. The quasi-periodic features of this variability can be represented by the NAO index phases.

During the years of NAO index maximum values, the surface wind speed over the south-western and north-eastern parts of the Black Sea becomes minimal, and the maximal - over the north-western, central and south-eastern parts. In the years of the NAO index minimum values, the surface wind speed over the eastern and south-western parts of the sea becomes maximal, and minimal - above the central and north-western parts (Fig. 4, $c, d$ ).

However, the NAO index represents the variability of only two atmospheric action centers affecting the Black Sea area [3]. The effect on the Black Sea wind field, in addition to the NAO, of other macro-circulating indices (for example, $E A$, $E A / W R, S C A, P O L$ ) has not been studied enough yet. Continuation of research in this field will contribute to a better understanding of the formation mechanism of the regional wind field mesoscale structure.

\section{Conclusion}

1. Analysis of the Black Sea wind speed module series $W$ according to the contact data showed the non-stationarity and multi-directionality of the spatialtemporal variability of the Black Sea wind field and at the same time the presence of stable quasi-periodic features close in its characteristics to similar characteristics of the NAO index variability.

2. Variability of all these series is characterized by the presence of three groups of oscillations with periods $T$ about 60-90, 20-40 and 3-15 years with the dominance of long-period ( $T \geq 60$ years) and mid-period ( $20 \leq \mathrm{T} \leq 40$ years) oscillations.

3. Calculated according to the MERRA array reanalysis, the mean anomalies of January - February average $W$ series separately for groups of years with the values of the NAO index $>+1$ and $<-1$ demonstrated in their dynamics the values of different signs for the same Black Sea areas. During the periods when the index positive phase is mainly predominant, the $W$ positive anomaly is formed over the south-western, south-eastern and eastern parts of the sea adjacent to the coast at a distance 20-100 km from it, and the $W$ negative anomaly - over the rest of the sea. During the years when the index phase is mainly negative, the signs of the $W$ anomalies over almost the same regions change to the opposite ones. 
Acknowledgements. The authors are grateful to Vladimir N. Belokopytov for the provided data of station measurements.

The work was carried out within the framework of the State Order No. 08272014-0011 Research of the Regularities of Changes in the Condition of the Marine Environment on the Basis of Operational Observations and Data of the System of Diagnosis, Prognosis and Reanalysis of the Condition of Marine Areas (Operational Oceanography).

\section{REFERENCES}

1. Monin, A.S. and Shishkov, Yu. A., 2000. Climate as a Problem of Physics [Klimat kak Problema Fiziki]. Uspekhi Fizicheskikh Nauk, 43(4), pp. 381-406. doi:10.1070/PU2000v043n04ABEH000678 (in Russian).

2. Frolov, A.V. ed., 2014. Vtoroy Otsenochnyy Doklad Rosgidrometa ob Izmeneniyakh Klimata i Ikh Posledstviyakh na Territorii Rossiyskoy Federatsii. Obshchee Rezyume [Second Assessment Report of Roshydromet on Climate Change and its Consequences in the Territory of the Russian Federation]. Moscow: Rosgidromet, 58 p. Available at: http://cc.voeikovmgo.ru/images/dokumenty/2015/od2.pdf [Accessed 19 June 2017] (in Russian).

3. Altman, E.N. and Simonov, A.I. eds, 1991. Gidrometeorologiya i Gidrokhimiya Morey SSSR. T. IV. Chernoe More. Vyp. 1. Gidrometeorologicheskie Usloviya [Hydrometeorology and Hydrochemistry of the USSR Seas. Vol. IV. The Black Sea. Iss. 1. Hydrometeorologic Conditions]. Saint-Petersburg: Gidrometeoizdat, 428 p. (in Russian).

4. Goryachkin, Yu.N. and Repetin, L.N., 2009. Shtormovoy Vetro-Volnovoy Rezhim u Chernomorskogo Poberezh'ya Kryma [Storm Wind and Wave Regime near the Black Sea Coast of Crimea. In: Ivanov, V.A. ed., 2009. Ekologicheskaya Bezopasnost' Pribrezhnoy i Shel'fovoy Zon i Kompleksnoe Ispol'zovanie Resursov Shel'fa [Ecological Safety of Coastal and Shelf Zones and Comprehensive Use of Shelf Resources]. Sevastopol: MHI NASU. Issue 19, pp. 56-69.

5. Bayankina, T.M., Sizov, A.A., Zhukov, A.N., Komarovskaya, O.I. and Pryakhina, S.F., 2015. Inter-Decadal Variability of the Wind Mode in the Black Sea Region. Physical Oceanography, [e-journal] (4), pp. 26-33, doi:10.22449/1573-160X-2015-4-26-33

6. Kara, A.B., Hurlburt, H.E., Wallcraft, A.J. and Bourassa, M.A., 2005. Black Sea Mixed Layer Sensitivity to Various Wind and Thermal Forcing Products on Climatological Time Scales. $J$. Climate, [e-journal] 18(24), pp. 5266-5293, doi:10.1175/JCLI3573R2.1

7. Bulgakov, N.P., Zhukov, A.N. and Sizov, A.A., 2004. Issledovanie Obshchikh Grupp Ustoychivykh Ritmov Mezhgodovoy Izmenchivosti Temperatury Vozdukha i Ryada Drugikh Protsessov v Pribrezhnykh Zonakh [Study of the General Groups of Steady Rhythms of the Interannual Variability of Air Temperature and the Series of Other Processes in the Coastal Zones]. Dopovidi NANU, (9), pp. 99-104 (in Russian).

8. Torrence, C. and Compo, G.P., 1998. A Practical Guide to Wavelet Analysis. Bull. Amer. Meteorol. Soc., [e-journal] 79(1), pp. 61-78, https://doi.org/10.1175/15200477(1998)079<0061:APGTWA>2.0.CO;2

9. Kistler, R., Collins, W., Saha, S., White, G., Woollen, J., Kalnay, E., Chelliah, M., Ebisuzaki, W., Kanamitsu, M. and Kousky, V. et al., 2001. The NCEP-NCAR 50-Year Reanalysis: Monthly Means CD-ROM and Documentation. Bulletin of the American Meteorological Society, [e-journal] 82(2), pp. 247-267, https://doi.org/10.1175/1520-0477(2001)082<0247:TNNYRM>2.3.CO;2

10. Rienecker, M.M., Suarez M.J., Gelaro R., Todling, R., Bacmeister, J., Liu, E., Bosilivich, M.G., Schubert, S.D., Takacs, L. and Kim, G.-K. et al., 2011. MERRA: NASA's Modern-Era Retrospective Analysis for Research and Applications. J. Climate, [e-journal] 24(14), pp. 3624-3648, doi:10.1175/JCLI-D-11-00015.1 
11. Byshev, V.I., Neiman, V.G., Romanov, Ju.A. and Serykh, I.V., 2014. Global Atmospheric Oscillations in Dynamics of the Recent Climate. Sovremennye Problemy Distantsionnogo Zondirovaniya Zemli iz Kosmosa [Current Problems in Remote Sensing of the Earth from Space], [e-journal] 11(1), pp. 62-71. Available at: http://jr.rse.cosmos.ru/article.aspx?id=1258 [Accessed: 20 June2017] (in Russian).

12. Wanner, H., Brönnimann, S., Casty, C., Gyalistras, D., Luterbacher, J., Schmutz, C., Stephenson, D. B. and Xoplaki, E., 2001. North Atlantic Oscillation - Concepts and Studies. Surveys in Geophysics, [e-journal] 22(4), pp. 321-381, doi:10.1023/A:1014217317898

13. Nesterov, E.S., 2013. Severoatlanticheskoe Kolebanie: Atmosfera i Okean [North Atlantic Oscillation: Atmosphere and Ocean]. Moscow: Triada Ltd, 144 p. Available at: http://method.meteorf.ru/publ/books/nesterov.pdf [Accessed 20 June 2017] (in Russian).

14. Hurrell Station-Based DJFM NAO Index, 2017. Available at: https://climatedataguide.ucar.edu/sites/default/files/nao_station_djfm.txt [Accessed 20 June 2017].

15. Zatsepin, A.G., Kremenetskiy, V.V., Poyarkov, S.G., 2002. Vliyanie Polya Vetra na Dinamiku Vod Chernogo Morya [The Wind Field Effect on the Dynamics of the Black Sea Waters]. In: A.G. Zatsepin, M.V. Flint eds., 2002. Kompleksnye Issledovaniya SeveroVostochnoy Chasti Chernogo Morya [Multidisciplinary Investigations of the Northeast Part of the Black Sea]. Moscow: Nauka, pp. 91-105 (in Russian).

16. Malinin, V.N. and Gordeeva, S.M., 2014. Severoatlanticheskoe Kolebanie i Uvlazhnenie Evropeyskoy Territorii Rossii [The North Atlantic Oscillation and Humidification of European Part of Russia]. Society. Environment. Development =TERRA HUMANA, [e-journal] (2), pp. 191-198. Available at: http://www.terrahumana.ru/arhiv/14_02/14_02_35.pdf [Accessed 20 June 2017] (in Russian).

17. Belokopytov, V.N., Kudryavtseva, G.F. and Lipchenko, M.M., 1998. Atmosfernoe Davlenie i Veter nad Chernym Morem (1961 - 1990 gg.) [Atmospheric Pressure and Wind over the Black Sea (1961-1990)]. In: UHMI, 1998. Proceedings of Ukrainian Hydrometeorological Institute. Iss. 246, pp. 174-181 (in Russian).

18. Ivanov, V.A. and Belokopytov, V.N., 2011. Okeanografiya Chernogo Morya. [Oceanography of the Black Sea]. Sevastopol: EKOSI-Gidrofizika, 209 p. (in Russian).

19. Rogers, J.C., 1997. North Atlantic Storm Track Variability and Its Association to the North Atlantic Oscillation and Climate Variability of Northern Europe. J. Climate, [e-journal] 10(7), pp. 1635-1647, doi:10.1175/1520-0442(1997)010<1635:NASTVA>2.0.CO;2 